\title{
sciendo
}

Folia Oeconomica Stetinensia

Volume 21 (2021) Issue 1

DOI: $10.2478 /$ foli-2021-0011
WYDZIAL NAUK EKONOMICZNYCH I ZARZĄDZANIA

\section{CUSTOMER ORIENTATION AND INNOVATION - THE PERSPECTIVE OF TOP-LEVEL MANAGEMENT}

\author{
Urszula Widelska, Ph.D. \\ Lomza State University of Applied Sciences \\ Faculty of Social Sciences and Humanities \\ Department of Management \\ e-mail: uwidelska@pwsip.edu.pl \\ ORCID 0000-0002-4273-936X
}

Katarzyna Krot, Ph.D.

Bialystok University of Technology

Faculty of Engineering Management

Department of Marketing and Tourism

e-mail:k.krot@pb.edu.pl

ORCID 0000-0002-7404-1724

Received 30 March 2020, Accepted 12 November 2020

\begin{abstract}
Research background: Scientific exploration of customer orientation also confirms the existence of connections which occur between the focus of an enterprise on the needs of its customers and the level of its innovativeness. For it is the customer and his/her needs that determine a company's primary directions of development and, in the end, the customer decides whether to make purchases and accept the company's offer

Purpose: The goal of the present study is the systemization of knowledge within the scope of customer orientation and dependencies that exist between innovativeness and customer orientation.

Research methodology: Inferences have been supported by the results of a CAWI quantitative survey conducted among 204 business leaders (top managers) from the Podlasie Voivodeship in Poland.

Results: The study results confirm that customer orientation within a company can vary in form and differ in character as well as indicate that innovation can determine the level of customer orientation within an enterprise.

Novelty: The study of the dependence between customer orientation and innovativeness is a challenge for management sciences and is subject to some limitations since both innovativeness as well as customer orientation are structures which are very complex and ambiguous. Innovation becomes a factor unifying a company with a customer because it guarantees the provision of new values and is the answer to the dynamic character of those changes.
\end{abstract}


Keywords: customer orientation, innovation, relationships with customers

JEL classification: L21, L22, M30, M31

\section{Introduction}

Customer orientation is considered to be an essential and integral element of a modern organization. Every enterprise is dependent on and enters into direct interactions with its customers. For it is the customer and his/her needs that determine a company's primary directions of development and, in the end, the customer decides whether to make purchases and accept the company's offer (Sheth, Sisodia, Sharma, 2000; Mazurek-Łopacińska, 2011). There is a clear refocusing of entities from a sales market to a customer market. The scientific exploration of customer orientation also confirms the existence of connections which occur between the focus of an enterprise on the needs of its customers and the level of its innovativeness (among others: Esty, Porter, 2005; AL-Dmour, Ahmad Amin, 2012; Roswening, Grinstein, 2015; Issau, 2019; Kankam-Kwarteng, Donkor, Acheampong 2019). The aim of this work is the systematization of knowledge concerning customer orientation and the identification of dependencies existing between innovativeness and customer orientation. Additionally, two research goals have been established. The first is the identification of types of customer orientation from the perspective of highest level managers while the second is the determination of dependencies between the type of customer focus and the level of an enterprise's innovativeness. Conclusions have been supported by the results of a CAWI quantitative study conducted among 204 business leaders (top-level managers) from the Podlasie Voivodeship. ${ }^{1}$ An analysis of the study results confirms that customer orientation within a company can vary in form and differ in character as well as indicates that innovations can determine the level of customer orientation within an enterprise.

\section{Customer orientation and innovation - an epistemological analysis}

In an attempt to systematize knowledge concerning customer orientation it is possible to define three basic directions of scientific exploration: customer orientation as a business philosophy, customer orientation as an area of organizational operations and customer

\footnotetext{
1 The research was conducted as part of project number 2017/01/X/HS4/01009 and was financed by the National
} Science Center. 
orientation as a concept of building value. An analysis of the marketing orientation within the category of business philosophy clearly points out the advantages which result from focusing on the customer and his/her needs. The implementation of such an approach in an organization may decide about gaining a competitive advantage (Kohli, Jaworski, 1990; Ganesan, 1994; Williamson, 1991), be an element of success (Hall, 1992) and impact profitability (Donaldson, 1993; Naver, Slater, 1990). In keeping with convention, the fulfillment of customers' needs and providing satisfaction better than the competition is described by researchers as essential while, at the same time, are difficult to implement organizationally (Capon, Farley, Hulbert, Lei, 1991). It is stressed that the gathering of knowledge about the market and customers is a necessary condition of attaining market success, not only in the context of better identification of target markets needs but also in the building of relationships between partners in the process of exchange (Julian, O’Cass, 2002) and focus on innovation (Park, Oh, Kasim, 2017). The evolution of thought within this area consists of changing focus from current target markets needs to the identification and fulfillment of future, unknown customer needs (Autachene-Gima, Slater, Olson, 2005; Ketchen, Hult, Slater 2007). The perception of marketing orientation in the categories of business philosophy is a challenge not only to managers directly engaged in the process of gaining and serving customers but also demands the full acceptance of the imperativeness of the customer as the enterprise's source of success.

According to some researchers, the executive perspective of customer orientation is insufficiently explored in management sciences (Saarijarvi, Kuusela, Neilimo, Narvanen, 2014). Treated as an organizational activity (executive) during which an enterprise develops processes and operations allowing the realization of the organizations aims resulting from building ties with customers. These actions include customer service systems, communication with the customers, market studies, decision processes and management of tasks resulting from interactions with target markets. Marketing orientation perceived as a certain set of activities and operations can offer numerous benefits not only in the form of satisfied customers but also as satisfied employees (Kohli, Jaworski, 1993), effective sales systems (among others: Siguaw, Simpson, Baker, 1998) and lasting competitive advantage (Dwyer, Tanner, 2002). The realization of activities resulting from customer orientation is not incidental but is rather long-term (Strandvik, Holmlund, Gronroos, 2014; Raaij, 2008). Strategic knowledge is, therefore, necessary and a top-level manager who has a long-term vision for the development of the enterprise should be both its source and disponent (see Gebhardt, Carpenter, Sherry, 2006; Folley, Fahy, 2014). 
Customer orientation based on customer value is founded on perceiving a customer as a source of value (among others Gallaz, Gil-Saura, 2011). Customer value is defined as the value which they bring to the organization (Dobiegała-Korona, 2008; Khalifa, 2004). Relations with the customer in the area of value take place when the customer continually receives expected value in a way that allows him/her to assume that the same level of anticipated value will also be received in the future (Gordon, 2001). Delivery of value by an enterprise produces an increase of customer loyalty mainly thanks to the expansion of their level of satisfaction resulting from purchases of products (Shin, Damon-Aiken, 2012).

Customer value within a modern organization can manifest itself, among others, in the following areas: inclusion of the customer into the essence of the process of value creation, agreement of the product with the simultaneous disclosure of the level of the purchaser's engagement, share in the diagnosis of problems, share in real production processes (Rogoziński, 2006). Studies into customer value also show that it can have a significant impact on the process of making strategic decisions within an enterprise (among others: Sanchez-Fernandez, IniestaBonillo, 2007). A customer-focused enterprise bases its cooperation with the customer on exchanging value with him/her - the customer becomes a valuable resource to the enterprise but only when he/she decides that the proposed offer will have economic, functional, symbolic and emotional value (Rintamaki, 2007). The value that customers bring into the organization, as well as the value which they receive in return, remains a strategic and key decision of the enterprise made at the highest level of management. Customer orientation is a part of the concept of the value chain and is, therefore, outside of the scope of buy-sell relationships. Customer orientation as a part of the value chain depends on the fulfillment and identification of customer needs through cooperation with all partners forming that chain (Hekkila, 2002; Nahm, 2004). It requires appropriate support in managing customer relations and remaining in constant contact with them. The flexibility of the enterprise consisting of adapting every element of the value chain to customers' changing needs as well as the improvement of the information system are, from the perspective of building and maintaining relationships with customers (Jeong, Hong, 2007), both very important. It should be stressed that an enterprise that is customer-oriented has a system for managing customers - a business strategy consisting of building long-term relationships with customers aimed at the maximization of customer satisfaction levels and the simultaneous minimalization of their loss (Tracey, Tran, 2001). Being oriented at the needs of customers requires cooperation at the inter-organizational level contributing to building cooperational ties (Park et al., 2017). 
The scientific exploration of customer orientation also confirms the existence of connections that are present between the focus of the enterprise on the needs of customers and the level of its innovativeness (among others Esty, Porter, 2005; AL-Dmour, Ahmad Amin, 2012; Roswening, Grinstein, 2015; Issau, 2019). The fulfillment of new and more frequently changing time requires the enterprise to react quickly through innovative products and services as well as how to utilize innovative methods for communicating with target markets. It should be stressed that key decisions which are a part of the competencies of top-level management (among others Domínguez-Escrig, Mallen-Broch, Lapiedra-Alcamí, Chiva-Gómez, 2018) include innovations. There are studies that confirm that enterprises that are more customer-oriented are also more open to innovation (among others: Franbach, Prabhu, Verhallen, 2003; Ford, Paladino, 2013; Shiaw-Tong, May-Chiun, Abang Azlan, Ramayah, 2018). Additionally, being customerfocused results in the initiation of activities increasing the company's effectiveness and, at the same time, providing desired values (among others: Han, Kim, Srivastava, 1998; Mahmoud, Blankson, Owusu-Frimpong, Nwankwo, Trang, 2016). Innovations, through strengthening the competitive position of the enterprise, provide the customer with new values. Researchers also show that innovation can be a factor determining customer orientation (among others: Keng, Huang, Zheng Hsu, 2007; Dobiegała-Korona, 2010). This occurs because providing the customer with new values makes focusing on his/her new needs necessary - innovation is not only the result of being customer-oriented but also a factor which intensifies that focus. Researchers, however, concentrate more on analyzing results where innovation is a consequence of customer orientation. There remains, nevertheless, a question: how much does an enterprise's focus on innovation impact its level of customer orientation? This area requires further, more in-depth analysis. The study of the dependence between customer orientation and innovativeness is a challenge for management sciences and is subject to some limitations since both innovativeness as well as customer orientation are structures which are very complex and ambiguous.

\section{Methodology}

Customer orientation, its form and scope remain within the competence of top-level management staff regardless of the approach. Leadership is one of the factors which determine the customer orientation of an enterprise. This is confirmed by past studies (Kennedy, Goolsby, Arnould, 2003; Kirca, Jayachandran, Bearden, 2005) since, regardless of the approach, a leader, the top-level manager, is directly involved in the process of implementing customer orientation within an enterprise. Decisions concerning customers, aside from the organization's structure 
or the management model used, are made at the highest level. The creation of customer value is an activity which is based on strategic decisions that fall into the scope of competencies of top managers and not only the personnel directly engaged in the process of customer service (among others: Saarijarvi et al., 2014). Study results also indicate that the manner in which an enterprise is managed can be a barrier to the development of the market competencies of a company (Harris, Ogbonna, 2001). Strategic knowledge is indispensable to realize tasks oriented at building relationships with customers and leaders, top managers who possess the long-term vision for the development of the company should be both its source as well as its disponents. According to the concept of this study, a leader (top-level manager) is a person who fulfills the following criteria:

1. Is the owner or, on account of being the founder of the enterprise (first owner), has influence on its development and is involved in making key decisions.

2. Manages an enterprise which employs at least 3 employees.

3. Manages an innovative enterprise implementing at least one type of product, process, technological or informational innovation.

The acceptance of boundary conditions listed above resulted from the conceptual nature of a leader. As has been mentioned earlier, leadership is a multidimensional category functioning within numerous concepts and theories (Kraszewski, Skrzypczyńska, 2016). The selection of the study respondents was a type of a compromise and it is obvious that the criteria accepted do not fully define respondents as leaders. However, the uncertainty whether the position one holds always predestines such a person to be a leader is certainly justified. For this reason, the approach that identifies a leader as a complete manager who can organize people and the available resources to successfully realize established goals as well as has the ability to lead an organization to achieve long-term success (Karaszewski, 2006) has been established as the starting point of the selection process. The acceptance of this perspective allowed the authors to conduct the study among top managers managing innovative enterprises. A review of past research output in the area of leadership and customer orientation shows that innovation is an integral part of both these concepts. Focus on innovation can be interpreted as being customer-oriented. Implemented innovations are a reaction to changing market conditions. For a leader, in turn, they are a tool for the improvement of the organization and an instrument for influencing its success.

The above considerations allowed the formulation of two study goals. The first consisted of the identification of customer orientation types from the perspective of top managers while the second included the determination of dependencies between types of customer orientation and the enterprise's level of innovativeness. 
Taking into account the above considerations, the results of a CAWI quantitative study, carried out among 204 business leaders (top managers) from the Podlasie Voivodeship, were used to draw conclusions. The choice of this method resulted from several reasons. First of all, this method makes it possible to reach a hard-to-reach sample, i.e. entrepreneurs (they can fill in the questionnaire at any time). In addition, you can control the course of the study by introducing restrictions and paths for filling in the questionnaire and monitor the sample structure on an ongoing basis. An additional advantage is the connection with the database. The study was conducted between June and October 2018. It included the participation of 204 leaders, with $9.3 \%$ of them being directors, $27.5 \%$ board presidents, $6.4 \%$ company owners and $40.2 \%$ department heads. The Podlasie Voivodeship is home to branches of numerous companies and that is the reason for the high percentage of department heads within the study. It should be noted that the survey is not representative; hence the formulated conclusions will apply only to the surveyed group of entrepreneurs.

In relation to the number of employees, the structure of the considered enterprises is consistent with the structure of enterprises represented throughout the whole Voivodeship. The largest number of respondents (46.6\%) managed companies employing between 10 and 49 workers. $43.1 \%$ of businesses employed from 3 to 9 employees. The share of enterprises engaging in excess of 250 workers was the least numerous. Industry categories in which respondents' enterprises operated were also consistent with industry representation throughout the Voivodeship. The greatest number of respondents managed service and sales enterprises (74.5\%). Construction companies made up $15.2 \%$ and production companies $10.3 \%$ of the sample.

\section{Study results}

The first goal of the study was to identify the types of customer orientation from the perspective of top managers. Customer orientation was measured using 17 statements presented to respondents using the 5 point Likert scale. Table 1 presents the descriptive statistics utilized within the analysis.

Table 1. Descriptive statistics of variables $(\mathrm{N}=204)$

\begin{tabular}{|l|c|c|c|}
\hline \multicolumn{1}{|c|}{ Variable } & Median & $\begin{array}{c}\text { Lower } \\
\text { quartile }\end{array}$ & $\begin{array}{c}\text { Upper } \\
\text { quartile }\end{array}$ \\
\hline \multicolumn{1}{|c|}{1} & 2 & 3 & 4 \\
\hline Quick reaction to the needs of the market decides about the enterprise's success & 4.00 & 3.00 & 5.00 \\
\hline The customer determines the enterprise's directions of development & 4.00 & 3.00 & 5.00 \\
\hline The customer is the organization's most important stakeholder & 4.00 & 3.00 & 5.00 \\
\hline
\end{tabular}




\begin{tabular}{|c|c|c|c|}
\hline 1 & 2 & 3 & 4 \\
\hline The customer is more than just a stakeholder - the customer is a resource & 4.00 & 3.00 & 5.00 \\
\hline Systematic monitoring of customers' needs and expectations is necessary & 4.00 & 4.00 & 5.00 \\
\hline $\begin{array}{l}\text { Maintaining relationships with existing customers is more difficult than getting } \\
\text { new customers }\end{array}$ & 4.00 & 3.00 & 4.00 \\
\hline $\begin{array}{l}\text { The ability to maintain relationships with existing customers is more important } \\
\text { than finding new customers }\end{array}$ & 4.00 & 3.00 & 5.00 \\
\hline The enterprise should be the creator of new needs and make new trends & 4.00 & 3.00 & 5.00 \\
\hline $\begin{array}{l}\text { The leader (top manager, owner) should have direct control over } \\
\text { the marketing department }\end{array}$ & 4.00 & 3.00 & 4.00 \\
\hline $\begin{array}{l}\text { The marketing department (commerce, sales dept.) is most responsible } \\
\text { for building relationships with customers }\end{array}$ & 4.00 & 3.00 & 4.00 \\
\hline $\begin{array}{l}\text { It is the customers and their needs who are the main source of inspiration for } \\
\text { new products and services }\end{array}$ & 4.00 & 3.00 & 5.00 \\
\hline The customer is primarily a partner not a source of profit & 4.00 & 3.00 & 4.00 \\
\hline A leader should focus on building close relationships only with key customers & 3.00 & 2.00 & 4.00 \\
\hline A factor that determines sales success is possessing customer service standards & 4.00 & 3.00 & 5.00 \\
\hline $\begin{array}{l}\text { It is possible to sell any product - everything depends on the skill } \\
\text { of the salesman }\end{array}$ & 4.00 & 3.00 & 5.00 \\
\hline The customer is a co-creator of product value & 4.00 & 3.00 & 4.00 \\
\hline The enterprise should aspire to expand internationally & 4.00 & 3.00 & 4.00 \\
\hline
\end{tabular}

Source: developed by the authors on the basis of the study results.

It was assumed that managers can declare types of customer orientation which could be mutually exclusive or can occur at the same time. For this reason, a factor analysis was performed using the principal components technique with Varimax rotation. The classification of variables was determined through the value of factor loadings. The threshold value of a factor loading for variable selection was established at 0.55. Cronbach's Alpha analysis was carried out for two of the isolated factors. In both cases, the indicator reached a satisfactory value, 0.95 and 0.84 respectively.

Table 2 presents factor loadings. The first factor named approach based on customer value consists of 10 statements drawing attention to the long-term role of customers as co-creators of products, as important stakeholders (P05_03, P05_04) determining the direction of an enterprise's development (P05_02). In this approach, the systematic monitoring of customers' needs and expectations (P05_05) as well as the ability to maintain relationships with existing customers (P05_07) are also very important. This approach is strategic in nature.

The second factor defined as the executive approach forms five statements that are operational in character. These indicate the traditional approach to marketing to be an isolated cell, dependent on top managers (P05_09; P05_10) with sales success being determined through possessing customer service standards (P05_14). 
Table 2. Results of a "customer orientation" factor analysis

\begin{tabular}{|l|c|c|}
\hline \multicolumn{1}{|c|}{ Variables } & $\begin{array}{c}\text { Factor } \\
\text { "approach based } \\
\text { on customer value" }\end{array}$ & $\begin{array}{c}\text { Factor } \\
\text { "executive } \\
\text { approach" }\end{array}$ \\
\hline The customer determines the enterprise's directions of development & 0.79 & \\
\hline The customer is more than just a stakeholder - the customer is a resource & 0.85 & \\
\hline $\begin{array}{l}\text { The ability to maintain relationships with existing customers is more } \\
\text { important than finding new customers }\end{array}$ & 0.61 & 0.74 \\
\hline The enterprise should be the creator of new needs and make new trends & 0.74 & \\
\hline $\begin{array}{l}\text { It is the customers and their needs who are the main source of inspiration } \\
\text { for new products and services }\end{array}$ & 0.68 & \\
\hline $\begin{array}{l}\text { It is possible to sell any product - everything depends on the skill } \\
\text { of the salesman }\end{array}$ & 0.71 & 0.86 \\
\hline The customer is a co-creator of product value & 0.87 & 0.63 \\
\hline $\begin{array}{l}\text { A quick reaction to the needs of the market decides about the enterprise's } \\
\text { success }\end{array}$ & 0.90 & 0.59 \\
\hline The customer is the organization's most important stakeholder & & 0.87 \\
\hline Systematic monitoring of customers' needs and expectations is necessary & & 0.69 \\
\hline $\begin{array}{l}\text { The leader (top manager, owner) should have direct control over the } \\
\text { marketing department }\end{array}$ & & 0.56 \\
\hline $\begin{array}{l}\text { The marketing department (commerce, sales dept.) is most responsible } \\
\text { for building relationships with customers }\end{array}$ & & 0.22 \\
\hline A leader should focus on building close relationships only with key customers & & \\
\hline $\begin{array}{l}\text { A factor that determines sales success is possessing customer service } \\
\text { standards }\end{array}$ & & \\
\hline The enterprise should aspire to expand internationally & & \\
\hline Share & & \\
\hline
\end{tabular}

Source: developed by the authors on the basis of the study results.

Referring to the second goal it was assumed that there is a dependency between customer orientation and the level of an enterprise's innovativeness. The greater the share of a company's profit which is utilized to implement innovations the greater their customer focus, or their engagement into being customer-oriented, must be. For this reason, the isolated dimensions of customer orientation were compared to answers to the question "what percentage of your company's last year's profit has been allocated to implement innovations?". The comparison was done using the U Manna-Whitney test (Table 3).

Table 3. Dependence between the approach based on customer value and the percentage of profit allocated to innovation

\begin{tabular}{|l|c|c|c|c|}
\cline { 2 - 5 } \multicolumn{1}{c|}{} & $\begin{array}{c}\text { Sum of ranks } \\
\text { group 1 }\end{array}$ & $\begin{array}{c}\text { Sum of ranks } \\
\text { group 2 }\end{array}$ & U & p-value \\
\hline Approach based on customer value & $9,701.00$ & $11,209.00$ & $3,923.00$ & 0.002 \\
\hline Executive approach & $9,930.00$ & $10,980.00$ & $4,152.00$ & 0.014 \\
\hline
\end{tabular}

Source: developed by the authors on the basis of the study results. 
Regardless of the type of customer orientation, the greater the percentage of profit used to implement innovations the greater the level of customer orientation.

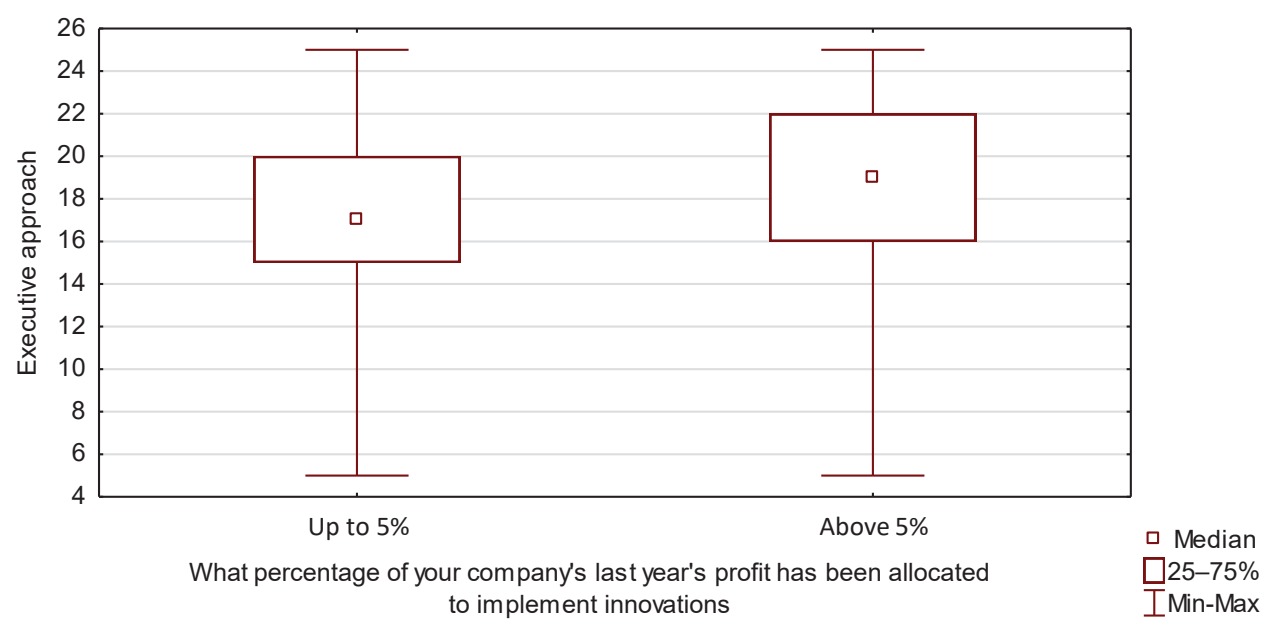

Figure 1. Dependence between the executive approach and the percentage of profit allocated to innovation

Source: developed by the authors on the basis of the study results.

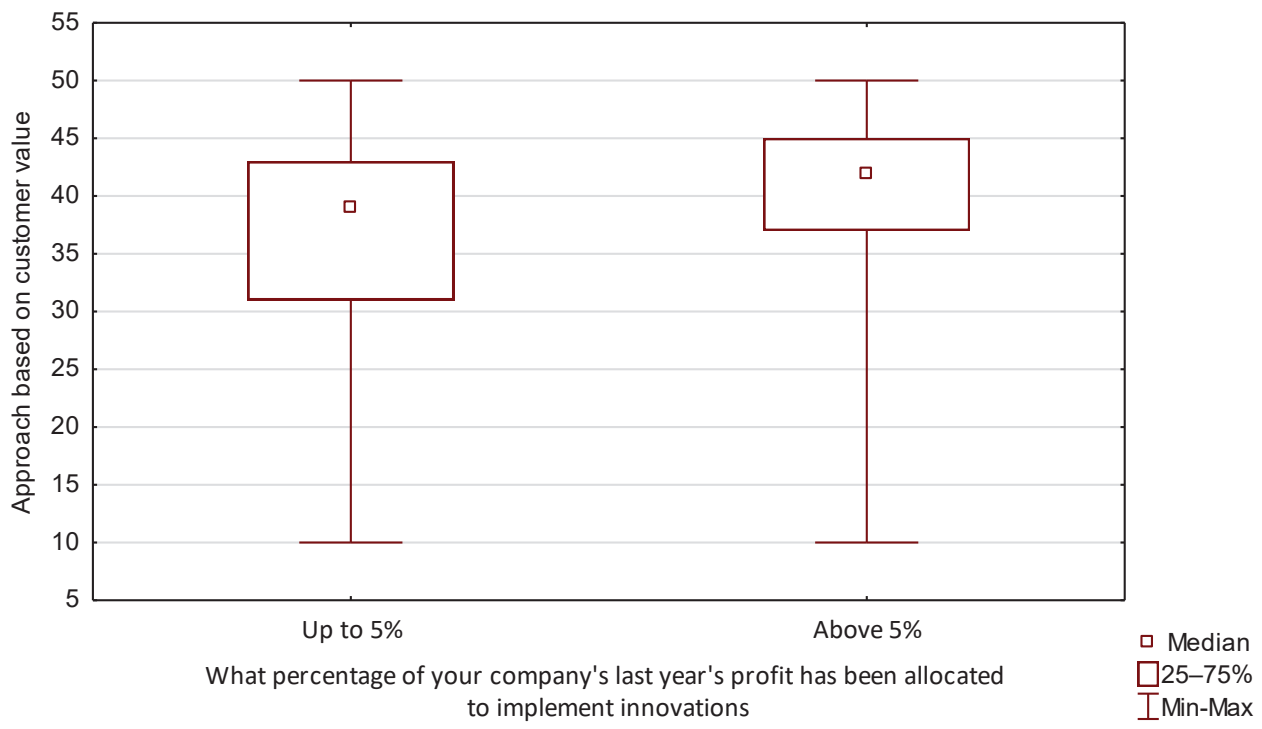

Figure 2. Dependence between the approach based on customer value and the percentage of profit allocated to innovation

Source: developed by the authors on the basis of the study results. 
Both with respect to orientation based on customer value as well as the executive approach differences between enterprises allocating below or above $5 \%$ of their profits are statistically significant.

\section{Conclusions}

As has been shown by the study results, customer orientation within an enterprise can take on different forms and vary in character. Despite the common conviction that the customer is undoubtedly an important resource of every organization, differences in approaches to the manner and scope of realizing customer orientation within an enterprise, have become apparent. This could be the result of the competitive position of a company but also of the characteristics, skills and approaches represented by its top-level managers. In the process of the analysis for the needs of the present work, two approaches toward customer orientation: the executive approach and the approach based on value have been identified. The executive approach can be identified with the traditional approach to the role of marketing in an organization and, what follows, to the customer. However, the approach based on customer value makes him/her a valuable co-creator of a company's offer and a key stakeholder with whom long-term cooperation brings both sides real profits. It turns out that innovation is not only the result of a strong customer orientation (among others: Esty, Porter, 2005, AL-Dmour, Ahmad Amin, 2012; Roswening, Grinstein, 2015; Issau, 2019) but can also be a factor increasing the level of a company's engagement in building strong relationships with customers (among others: Ford, Paladino, 2013; Shiaw-Tong, 2018; Kankam-Kwarteng, Donkor, Acheampong, 2019).

Enterprises that allocated a greater percentage of their profits for innovation were, regardless of the approach used, more customer-oriented. This can be the result of the growing awareness of top-level managers that customer orientation is an integral element of strategy taking into account changes in the needs, behaviors and attitudes of customers. What is more, this dependence is also statistically significant in companies whose managers declared having an executive approach. Innovation, therefore, becomes a factor unifying the company with the customer because it guarantees the provision of new values and is the answer to the dynamic character of those changes. Innovations also stimulate greater engagement in the process of their marketization. Providing customers with information about innovation and building an awareness of its existence also determines the level of a company's engagement into building relationships with customers. It must be remembered, however, that the obtained results possess certain limitations. Giving consideration to only one independent variable, the percentage 
of spending for innovation, does not reflect the complexity of the issue of innovativeness and, at the same time, does not fully explain the character of the relationship with the customer.

\section{References}

Atuahene-Gima K., Slater, S.F., Olson, E.M. (2005). The contingent value of responsive and proactive market orientations for new product program performance. Journal of Product Innovation Management, 22 (6), 464-482.

Capon, N., Farley J., Hulbert, J., Lei, D. (1991). In search of excellence ten years later: strategy and organization do matter. Management Decision, 29 (4), 12-21.

Dmour, H.H., Ahmad Amin, E.B. (2012). The effect of market orientation on service innovation: A study on the information and communication technology sector in Jordan. International Journal of Humanities and Social Science, 2 (19), 42-46.

Dobiegała-Korona, B. (2010). Strategie innowacji w budowie kapitału klienta, In: B. Dobiegała-Korona, T. Doligalski (eds.), Zarządzanie wartościa klienta. Pomiar i strategie. Warszawa: Poltext.

Domínguez-Escrig, E., Mallen-Broch, F.F., Lapiedra-Alcamí, R., Chiva-Gómez, R. (2018). The Influence of Leaders' Stewardship Behavior on Innovation Success. The Mediating Effect of Radical Innovation: Journal of Business Ethics, 159, 849-862.

Donaldson, B. (1993). Customer driven organizations can smile (pp. 243-255). Proceedings of the Annual Conference of the Marketing Education Group, 1, Loughborough University Business School, Loughborough.

Dwyer, R.F., Tanner, J.F. (2002). Business Marketing: Connecting Strategy. Relationships, and Learning. 2nd ed. New York, NY: McGraw-Hill.

Esty, D.C., Porter, M.E. (2005). National environmental performance: an empirical analysis of policy results and determinants. Environment and Development Economics, 10 (4), $391-434$.

Ford, D., Paladino, A. (2013). Enabling innovation through strategic synergies. Journal of Product Innovation Management, 30 (6), 1058-1072.

Franbach, R.T., Prabhu, J., Verhallen, J.T.M. (2003). The influence of business strategy on new product activity: The role of market orientation. International Journal of Research in Marketing, 20 (4), 377-397.

Gallarza, M.G., Gil-Saura, I. (2011). The value of value: further excursions on the meaning and role of customer value. Journal of Consumer Behaviour, 10 (4), 179-191. 
Ganesan, S. (1994). Determinants of long-term orientation in buyer-seller relationships. Journal of Marketing, 58 (April), 1-19.

Gebhardt, G.F., Carpenter, G.S., Sherry, J.F. Jr (2006). Creating a market orientation: a longitudinal, multifirm, grounded analysis of cultural transformation. Journal of Marketing, $70(4), 37-55$.

Gordon, I.H. (2001), Relacje z klientem. Marketing partnerski. Warszawa: PWE.

Hall, D. (1992). The Hallmarks for Successful Business. London: Mercury Books.

Han, J.K., Kim, N., Srivastava, R.K. (1998). Market orientation and organizational performance: Is innovation a missing link? The Journal of marketing, 30-45.

Harris, L.C., Ogbonna, E. (2001). Leadership style and market orientation: an empirical study. European Journal of Marketing, 35 (5/6), 744-764.

Issuau, K. (2019). Role of Market Orientation on Innovation Orientation of Manufacturing SMEs in the Accra, Metropolis, Ghana. Journal of Entrepreneurship and Business, 7 (1), 40-51.

Jeong, J.S., Hong, P. (2007). Customer orientation and performance outcomes in supply chain management. Journal of Enterprise Information Management, 20 (5), 578-594.

Julian, C.C., O'Cass, A. (2002). Examining the internal-external determinants of international joint venture (IJV) marketing performance in Thailand. Australasian Marketing Journal, $10(2), 55-71$.

Karaszewski, R. (2006). Nowoczesne systemy zarządzania jakością. Toruń: TNOiK.

Keng, C.J., Huang, T.L., Zheng, L.J., Hsu, M.K. (2007). Modeling service encounters and customer experiential value in retailing: An empirical investigation of shopping mall customers in Taiwan. International Journal of Service Industry Management, 18 (4), 349-367.

Kennedy, K.N., Goolsby, J.R., Arnould, E.J. (2003). Implementing a customer orientation: extension of theory and application. Journal of Marketing, 67 (4), 67-81.

Ketchen Jr, D.J, Hult, G.T.M, Slater, S.F. (2007). Toward greater understanding of market orientation and the resource-based view. Strategic Management Journal, 28 (9), 867-964.

Khalifa, A.S. (2004). Customer value: a review of recent literature and an integrative configuration. Management Decision, 42 (5/6), 645-666.

Kirca, A.H., Jayachandran, S., Bearden, W.O. (2005). Market orientation: a meta-analytic review and assessment of its antecedents and impact on performance. Journal of Marketing, $69(2), 24-41$.

Kohli, A., Jaworski, B. (1990). Market orientation: the construct, research proposition, and managerial implications. Journal of Marketing, 54 (April), 1-18.

Kankam-Kwarteng, C., Donkor, J., Acheampong, S. (2019). Measuring Performance of SMEs Service Firms Customer Orientation and Service Innovation Approach. Journal of Management Research, 19 (2), 103-119. 
Kraszewski, R., Skrzypczynska, K. (2016). Przywództwo w biznesie. Toruń: TNOiK.

Mahmoud, M.A., Blankson, C., Owusu-Frimpong, N., Nwankwo, S., Trang, T.P. (2016). Market orientation, learning orientation and business performance: The mediating role of innovation. International Journal of Bank Marketing, 34 (5), 623-648.

Mazurek-Łopacińska, K. (2011). Orientacja na klienta. Warszawa: PWE.

Nahm, A.Y., Vonderembse, M.A., Koufteros, X. (2004). The impact of organizational culture on time-based manufacturing and performance. Decision Sciences, 35 (4), 579-607.

Park, C., Oh, C.H., Kasim, A. (2017). Market challenges, learning and customer orientation, and innovativeness in IJVs. International Marketing Review, 34 (6), 945-967.

Rintamaki, T., Kuusela, H., Mitronen, L. (2007). Identifying competitive customer value propositions in retailing. Managing Service Quality, 17 (6), 621-634.

Rogoziński, K. (2006). Klient jako współtwórca wartości. Marketing i Rynek, 8.

Saarijarvi, H., Kuusela, H., Neilimo, K., Narvanen, E. (2014). Disentangling customer orientation - executive perspective. Business Process Management Journal, 20 (5), 663-677.

Sanchez-Fernandez, R., Iniesta-Bonillo, M.A. (2007). The concept of perceived value: a systematic review of the research. Marketing Theory, 7 (4), 427-451.

Sheth, J.N., Sisodia, R.S., Sharma, A. (2000). The antecedents and consequences of customercentric marketing, Academy of Marketing Science, 28 (1), 55-66.

Shiaw-Tong, H., May-Chiun, L., Abang Azlan, N., Ramayah, T. (2018). Determinants of Innovation Performance among SMEs: Moderating Effect of Entrepreneurial Orientation. Global Business and Management Research. An International Journal, 10 (2), 241-252.

Siguaw, J., Simpson, P., Baker, T. (1998). Effects of supplier market orientation on distribution market orientation and the channel relationships: the distributor perspective. Journal of Marketing, 62 (3), 99-111.

Shin, S., Damon Aiken, K. (2012). The mediating role of marketing capability: evidence from Korean companies. Asia Pacific Journal of Marketing and Logistics, 24 (4), 658-677.

Strandvik, T., Holmlund, M., Gronroos, C. (2014). Mental footprint of marketing in the boardroom. Journal of Service Management, 25 (2), 241-252.

Tracey, M., Tan, C. (2001). Empirical analysis of supplier selection and involvement, customer satisfaction, and firm performance. Supply Chain Management: An International Journal, $6(4), 174-188$. 